\section{The fall agenda}

Congress has outlined an aggressive agenda for the fall. Whether the House and Senate will be able to act on all the items before the November elections seems unlikely, though technically possible. A "must do" for Congress is to pass the FY2003 Appropriations bills. This is all amidst the cacophony of debate over President Bush's proposed Department of Homeland Security, the invasion of Iraq, and antiterrorism efforts.

The library community has been seeking additional funding for the Library Services and Technology Act (LSTA) in the Labor, Education, Health and Human Services appropriations bill as well as needed funding for legislative branch appropriations, including the Government Printing Office (GPO). For the latest on LSTA and appropriations go to http:// www.ala.org/washoff/alawon/alwn1169.html.

In addition, two copyright issues of importance to librarians could move quickly through Congress this fall.

\section{Anti-counterfeiting legislation}

S. 2395, the Anti-counterfeiting Amendments of 2002, sponsored by Senator Joseph Biden (D-Delaware), is intended to create liability for trafficking in illicit authentication features-a hologram, watermark, certification, symbol, code, or other means of designating that the product to which the authentication feature is affixed is authentic. The bill could pose major problems for anyone exercising fair use.

The library community is concerned that the bill could adversely impact librarians using interlibrary loan and making preservation copies of works. Potentially, if the TEACH Act is enacted to update the copyright law for distance education, the distribution of copyrighted material without permission from the copyright owner could constitute a violation of the antitrafficking provisions of S. 2395. The kinds of works included in the bill are phonorecords,

Lynne E. Bradley is Office of Government Relations director of ALA's Washington Office, e-mail: leo@alawash org and Miriam Nisbet is ALA Legislative Council, e mail:mnisbet@alawash.org computer programs, and motion pictures and other audiovisual works, all of which could be included in otherwise exempt transactions.

This bill modifies the U.S. criminal code so that potential copyright infringement transactions - or even exempt uses such as fair usecould be subject (via trafficking in illicit authentication measures) to criminal penalties including imprisonment. ACRL members are asked to contact their senators to let them know that this bill should not be passed until it receives careful analysis and until hearings are held. For additional background details and talking points, as well as information about the latest status of the bill and who your senators are and how to contact them, see our Web site at http:/ www.ala.org/washoff/alawon/alwn1166.html or contact your Congressional offices through the U.S. Capitol switchboard at (202) 224-3121.

\section{Database protection}

There have been extensive discussions throughout the 107 th Congress among staff members of the House Energy and Commerce Committee and the House Judiciary Committee to draft a database protection bill that would be acceptable to all stakeholders, including libraries and universities. There is no compromise legislation, although a bill may be introduced in the House this fall.

We have now learned that one of the primary proponents of a broad database protection bill has been asking various senators to sponsor a bill that our database coalition would find highly objectionable. Here's another critical issue for which we need ACRL supporters to contact their senators and lobby to not move on any database protection bill without hearings that include all stakeholders. Please let your senators and representative know that we believe that current copyright laws are more than adequate to protect these interests.

Note: The debate over the proposed elimination of PubSCIENCE continues. Follow this issue and how ALA, in collaboration with ACRL, has responded to the latest salvos at: http:// www.ala.org/washoff/alawon/alwn1170.html Special thanks to former ACRL President Susan Martin for her contributions to this effort. 